\title{
'N VERGELYKENDE STUDIE NA DIE VLAK EN OORSAKE VAN WERKSTRES BY 'N GROEP GELETTERDE EN ONGELETTERDE SWART WERKNEMERS
}

\author{
EBBEN VAN ZYL \\ COEN BESTER \\ Departement Bedryfsielkunde \\ Universiteit van die Oranje-Vrystaat
}

\begin{abstract}
A comparable study into workstress amongst a group of literate and illiterate black employees. Despite the fact that the South African black employee experience a broad spectrum of stressors, there is limited research which describes their actual levels and typical causes of stress. It was decided then to identify and to compare South African literate and illiterate black employees' level and causes of stress. This information could help psychologists/employers to maintain a distinctive approach in communicating and handling problems with the distinguish groups. In order to identify black employees' level and causes of stress the Experience of Work and Life Circumstances questionnaire was applied on an occasional sample of 60 persons. Results showed that illiterate black employees' levels of stress were significantly higher than the literate group. Furthermore, the illiterate group scored significantly higher scores than the literate group on the following causes of stress: causes outside the work situation, task characteristics, physical working conditions and job equipment, social matters as well as remuneration and fringe benefits. In the light of the abovementioned results a few recommendations were made.
\end{abstract}

\section{OPSOMMING}

Nieteenstaande die feit dat die Suid- Afrikaanse swart werknemer aan 'n breë spektrum van stressors blootgestel word, bestaan daar relatief min navorsing wat hul werklike vlak en tipiese oorsake van stres uitwys. Derhalwe is besluit om geletterde en ongeletterde swart werknemers se vlakke en oorsake van stres te identifiseer en te vergelyk. Met die inligting sal dit veral sielkundiges en werkgewers in staat stel om'n effektiewe benadering ten opsigte van die kommunikasie en hantering van probleme met die onderskeie groepe te kan handhaaf. Die Ervaring van werk -en lewensomstandighede vraelys is op 'n geleentheidsteekproef van 60 persone afgeneem. Resultate toon dat ongeletterde swart werknemers se vlakke van stres beduidend hoër as die van die geletterde groep is. Verder het die ongeletterde groep beduidend hoër tellings op die volgende oorsake van stres behaal: oorsake van stres binne die werk, taakeienskappe, fisiese werkomstandighede, sosiale aspekte sowel as vergoeding en byvoordele. In die lig hiervan is enkele aanbevelings gemaak.

\section{SYNOPSIS}

According to literature and previous research findings the South African black employee experiences a broad spectrum of stress. There is limited research which describes the black employees' actual levels and typical causes of stress. Due to the fact that that educational level can contribute to the effective managing of stress and consequent lower levels of stress, it was decided to identify and compare South African literate and illiterate black employees' levels and causes of stress. This information could help psychologists/employers to maintain a distinctive approach in communicating and handling problems with the distinguished groups.

The approach regarding stress that has been adopted for purposes of this study is the stimulus-response approach. According to this assumption job stress is the individual's response to attributes of the work environment which are perceived as been threatening by the individual.

The Experience of Work and Life Circumstances questionnaire was applied on an occasional sample of 60 subjects of a transport company in order to identify black employees' levels and causes of stress. This questionnaire is specifically developed and standardised for the South African context with a reliabilty coefficient that varies between 0,62 and 0,92. The construct validity is also fairly high. It measures the individuals general level of stress as well as causes of stress inside and outside the work environment. Causes of stress within the work situation include organisational functioning, task characteristics, physical working conditions and job equipment, career issues, social matters as well as remuneration and fringe benefits.

The subjects were divided in two respective groups, namely a group of 30 literate and 30 illiterate subjects of a transport company. Subjects were requested to provide information regarding their sex, period of service, age, qualifications and mother tongue.

Results showed that illiterate black employees' levels of work stress were significant higher than the literate group. Furthermore, the illiterate group scored significantly higher scores than the literate group on the

Requests for copies should be addressed to: T Groenewald, Technikon SA, Private Bag X6, Florida, 1710 following causes of stress: causes outside the work situation, task characteristics, physical work conditions and job equipment, social matters as well as remuneration and fringe benefits.

Useful recommendations regarding steps that organisations can take to empower their illiterate and literate labour force to manage job stress more effectively, have been made.

Navorsing dui daarop dat Suid-Afrikaners hoë vlakke van stres ervaar. So wys Van Zyl, (1996, p. 1) en Motshabi in Pienaar (1998) daarop dat stresverwante toestande in SuidAfrika by die werk sowel as tuis an die toeneem is en dat dit anleiding gee tot die hoë stresvlakke onder Suid-Afrikaners. Sullivan (1995, p. 1) meld dat stres blykbaar die endemiese siekte van die nuwe millenium is en dat dit veral die geval in Suid-Afrika is waar die effek van die wêreldresessie deur 'n onstabiele en snel veranderende sosiale en politieke klimaat vererger word. Die impak van stres word dus op alle vlakke van die samelewing van die individu tot op nasionale vlak ervaar.

\section{SWART WERKNEMERS EN STRES}

Dit blyk dat swart werknemers by die groep Suid-Afrikaners wat aan hoë stres ly, ingesluit kan word. Navorsing (Davies, 1986, pp. 14-30; Moerdyk, 1983, pp. 18-47; Outlaw, 1993, Smallegan, 1989, pp. 4 - 8; Van Zyl, 1991, pp. 72-6;) toon dat laervlak (ongeletterde) swart werknemers aan 'n breë spektrum stressors in die werksituasie blootgestel is (byvoorbeeld onvoldoende opleidingsgeleenthede, swak kommunikasie, moeilike/ongemaklike liggaamlike eise, min deelname aan besluitneming en min sekuriteit). Pienaar (1998) wys daarop dat stereotipering van en vooroordeel teenoor die laervlakwerknemer asook die min gesag wat hy het, 'n rol in sy ervaring van stres mag speel.

Voorts wys Van Zyl (1991, pp. 92-96 en 1996) asook Moerdyk (1983) daarop dat stressors binne die sosio-psigologiese en breë sosiale konteks van die laervlakwerknemer, naamlik onvol- 
doende geriewe (byvoorbeeld watertoevoer en elektrisiteit), onvoldoende behuising, finansiële probleme, veranderinge (byvoorbeeld tegnologiese veranderinge), gesinskrisisse (byvoorbeeld siekte of dood) en vervoerprobleme ook tot hoë stresvlakke aanleiding gee.

Davies (1986), Cooper en Sutherland (1990), Prins (1995, p. 32), Van Zyl (1994, p. 22) en Pienaar (1998, p. 3) is ook van mening dat geletterde swart hoërvlakwerknemers 'n verskeidenheid van probleme ervaar. Probleme in die werksituasie sluit in oorlaai met werk, druk van tyd, 'n gebrek aan toepaslike bestuurservaring en ander historiese faktore. Ngwezi (1988; p. 90) meld dat senior swart werknemers se persoonlike huislike lewe dikwels geraak word deur die ekstra tyd wat aan hulle werk gewy word, fisiese dreigemente in die township waar hulle woon en te min ontspanningsgeriewe (byvoorbeeld muurbalbane en gholfbane). Reese (in Van Zyl, 1991, pp. 7576) is van mening dat swart seniorvlakwerknemers ook probleme het met die aanpassing by 'n Westerse werk kultuur waar hulle nie in staat is om outonoom te funksioneer en/of om verhoogde verantwoordehikheid te aanvaar nie. Reese (1981) stel dit soos volg: "the cultural inheritance of some South African blacks is such that they display affiliation needs rather than achievement needs. They are used to doing things by group consensus and now individualistically" en "studies confirm the fact that some high level black workers have problems to function autonomously and to handle increased responsibility. The weak achievement needs of those blacks have been identified as the main cause of the problem". Pienaar (1998) is van mening dat sommige ambisieuse swartes geneig is om oor min toepaslike besigheids- en bestuursverwante ervaring beskik. In hierdie opsig het hulle'n nadeel teenoor hulle blanke eweknieë wat dikwels deur hulle huislike omgewing blootstelling aan praktiese besigheid- en bestuursbeginsels het (Pienaar, 1998, p. 3)

Ondanks die feit dat die Suid-Afrikaanse swart werknemer'n breë spektrum stressors ervaar, is min navorsing beskikbaar wat hulle werklike stresvlak kan beskryf. Olivier (1989) toon aan dat werknemers van verskillende kultuurgroepe die volgende persentasies hoë stres ervaar: blankes: 38,1\%; kleurlinge: $34,7 \%$ en swartes: $35 \%$. Dit is egter nie duidelik op watter vlak hierdie mense was nie en of meetinstrumente gestandaardiseer en resultate vir beduidendheid getoets is nie. Moerdyk (1983) wys op die behoefte om die vlak en oorsake van stres onder hoër- en laervlak- swart werknemers op te klaar en te vergelyk ten einde meer doeltreffende hanteringstrategieë voor te stel en te implementeer. Gerdes (1992, p. 42) stel dit soos volg: "The identification of a risk group necessitates provision of training and handling of health problems in a preventive way." Sy voer aan dat gesondheidbestuurstrategieë proaktief en voorkomend moet wees, want wanneer werknemers hoë stres ervaar en om hulp vra, is hul gesondheid en produktiwiteitsvlakke waarskynlik reeds negatief beïnvloed (Gerdes, 1992, pp. 42-43). Proaktiewe stappe kan gedoen word as meer inligting oor tipiese vlakke en oorsake van stres onder hoër- en laervlakwerknemers beskikbaar is.

Ter ondersteuning en ter aanvulling van bogenoemde studies is daar besluit om geletterde en ongeletterde swart werknemers se vlakke en oorsake van stres te identifiseer en te vergelyk. Hierdie inligting kan sielkundiges/werknemers help om 'n effektiewe benadering ten opsigte van kommunikasie en die hantering van probleme met hulle te handhaaf

\section{BENADERING TOT STRES}

Uit navorsing is dit duidelik dat verskeie benaderings van stres al gebruik is om voorspellers van stres te bepaal (Auerbach en Gramling,1998; Cartwright en Cooper, 1997; Cooper en Sutherland, 1990; Gatto, 1991; Lazarus, 1999; Lazarus, 1994; Outlaw 1993; Patel, 1991; Smith, 1993; Spielberger en Reheiser, 1994).

Ooreenkomstig bogenoemde navorsing kan werkstres beskou word as 'n individu se reaksie op eienskappe van die (werk) omgewing wat deur die individu as bedreigend beskou word (stimulus-responsbenadering). Dit dui op'n swak passing tussen die individu se vermoë en eise vanuit die omgewing soos deur die individu geëvalueer.

Vir doeleindes van die studie word daar dus op die persoon se vermoë om by sy omgewing aan te pas gefokus, waarvolgens die individu negatief sal reageer op eise vanuit sy (werk)omgewing indien die eise as bedreigend geëvalueer word. Die benadering is gekies hoofsaaklik omdat dit eenvoudig en werk-baar is en in resente navorsing (Barnett en Brennan,1995; Bartlett, 1998; Lazarus 1991, 1994; Pienaar, 1998; Sullivan, 1995; Van Zyl en Van der Walt, 1994 en Van Zyl, 1996) gebruik word.

\section{METODOLOGIE}

\section{Formulering van hipotese}

Die volgende teoretiese hipoteses $(\mathrm{Hl})$ is geformuleer:

Hipotese 1: Swart geletterde en ongeletterde werknemers ervaar statisties beduidende verskillende vlakke van stres.

Hipotese 2: Swart geletterde en ongeletterde werknemers ervaar statisties beduidende verskillende tellings op oorsake van stres.

Hierteenoor kan die volgende nulhipoteses $(\mathrm{HO})$ geformuleer word.

Nulhipotese 1: Die stresvlakke van geletterde en ongeletterde swart werknemers verskil statisties nie beduidend van mekaar nie.

Nulhipotese 2: Die oorsake van stres by geletterde en ongeletterde swart werknemers verskil statisties nie beduidend van mekaar nie.

In die studie is 'n nulhipotese aanvaar as die waarskynlikheid meer as $95 \%$ was dat die verskille die gevolg van toevallige faktore was.

\section{Navorsingsontwerp}

Die opnamemetode van navorsing is gebruik aangesien'n selfevaluasievraelys (die Ervaring van Werk- en Lewensomstandighede Vraelys) in groepverband afgeneem is.

\section{Ondersoekgroep}

'n Geleentheidsteekproef van 30 geletterde asook 30 ongeletterde swart werknemers by 'n groot vervoermaatskappy is gebruik (by ongeletterde werknemers word bedoel persone wat oor geen formele kwalifikasies beskik nie en ook nie kan lees of skryf nie). Die meeste van die respondente is hande-arbeiders, drywers en bodes. Omdat 'n geleentheidsteekproefgebruik is, kan die resultate nie veralgemeen word tot alle geletterde en ongeletterde werknemers nie. Werknemers wat vrywillig wou deelneem, is oor 'n tydperk van twee dae getoets nadat die doel van die toetssessie verduidelik is en hulle gevra is om vraelyste anoniem in groepkonteks in te vul. Ongeletterde werknemers het Sotho-sprekende instrukteurs ontvang. Die Sotho-sprekende instrukteurs het die laervlak werknemers ook gehelp om op elke vraag te respondeer. Vrae is vertaal en op konkrete wyse beskryf/verduidelik sodat hulle dit kon verstaan (verwys na Van Zyl en Van der Walt, 1994 waar bevind is dat laervlak swartes stres op 'n konkrete manier verstaan). Voorts is bykomende tyd met laervlakwerknemers bestee om moontlike misverstande op te los. Persone is versoek (en toestemming is van hulle werkgewer verkry) om hulle geslag, dienstydperk, ouderdom, kwalifikasie en huistaal te vermeld. Besonderhede van die groepe word in tabel 1 aangegee.

\section{Die meting van stres}

Die Ervaring van Werk- en Lewensomstandighede Vraelys (WLV) is 'n gestandaardiseerde B-vlak selfbeoordelingvraelys wat deur die Raad vir Geesteswetenskaplike Navorsing (RGN) ontwikkel is om die vlakke en oorsake van stres by werknemers van verskillende kultuurgroepe te bepaal (Van Zyl \& Van der Walt, 1991). Die WLV is konstruktueel geldig aangesien die verwagte verband met toepaslike persoonlikheidstoetse getoon 
word. Betroubaarheidskoeffisiënte soos deur die Kuder Richardson-formule 8 en met toets-hertoets gemeet is, varieer tussen 0,62 en 0,92 (Van Zyl \& Van der Walt, 1991).

TABLE 1

BIOGRAFIESE INLIGTING VAN DIE ONDERSOEKGROEPE

\begin{tabular}{|c|c|c|c|c|}
\hline \multirow[b]{2}{*}{$\mathrm{N}=30$} & \multicolumn{2}{|c|}{ GELETTERDE GROEP } & \multicolumn{2}{|c|}{ ONGELETTERDE GROEP } \\
\hline & $\mathrm{N}$ & $\%$ & $\mathrm{~N}$ & $\%$ \\
\hline GESLAG & 25 & $83,3 \%$ & 30 & 100,0 \\
\hline Manlik & 5 & 16,7 & 0 & 0 \\
\hline \multicolumn{5}{|l|}{ Vroulik } \\
\hline TOTAAL & 30 & 100,0 & 30 & 100,0 \\
\hline \multicolumn{5}{|l|}{ DIENSTYDPERK } \\
\hline 2 jaar & 7 & 23,3 & 0 & 0 \\
\hline $2-5$ jaar & 7 & 23,3 & 0 & 0 \\
\hline $6-10$ jaar & 2 & 6,7 & 11 & 36,7 \\
\hline$>10$ jaar & 13 & 43,4 & 19 & 63,3 \\
\hline Geen respons & 1 & 3,3 & 0 & 0 \\
\hline TOTAAL & 30 & 100,0 & 30 & 100,0 \\
\hline \multicolumn{5}{|l|}{ OUDERDOM } \\
\hline$<20$ & 0 & 0 & 0 & 0 \\
\hline $20-29$ & 14 & 46,7 & 1 & 3,3 \\
\hline $30-39$ & 11 & 36,7 & 11 & 36,7 \\
\hline $40-49$ & 4 & 13,3 & 15 & 50,0 \\
\hline $50-59$ & 0 & 0 & 3 & 10,0 \\
\hline$>60$ & 1 & 3,3 & 0 & 0 \\
\hline TOTAAL & 30 & 100,0 & 30 & 100,0 \\
\hline \multicolumn{5}{|l|}{ HUISTAAL } \\
\hline Afrikaans & 6 & 20,0 & 1 & 3,3 \\
\hline Engels & 1 & 3,3 & 0 & 0 \\
\hline Sotho & 22 & 73,4 & 26 & 86,7 \\
\hline Venda & 1 & 3,3 & 3 & 10,0 \\
\hline TOTAAL & 30 & 100,0 & 30 & 100,0 \\
\hline \multicolumn{5}{|l|}{ KWALIFIKASIES } \\
\hline Geen kwalifikasie & - & 0 & 30 & 100 \\
\hline St. 10 & 19 & 63,3 & & \\
\hline Hoër as St. 6 & 11 & 36,7 & & \\
\hline TOTAAL & 30 & 100,0 & 30 & 100,0 \\
\hline
\end{tabular}

Die vraelys is gebaseer op 'n spesifieke benadering ten opsigte van stres wat aansluit by die teoretiese benadering (stimulusresponsbenadering) wat in die studie gebruik is. Volgens hierdie benadering is die fokus op die swak passing tussen die individu se vermoë en eise vanuit die omgewing. Ten opsigte van stresvlak asook oorsake van stres buite die werksituasie dui 'n hoe telling op hoë stres, in teenstelling met oorsake van stres in die werksituasie waar'n lae telling op hoë stres dui.

\section{Dataontleding}

Geletterde en ongeletterde werknemers se stresvlakke en oorsake van stres sal deur middel van 'n reeks eenrigting variansieontleding (anova) vergelyk word om te toets of groep gemiddeldes beduidend verskil.

\section{RESULTATE}

Vlakke van stres: verskille tussen groepe

Die stresvlakke vir geletterde en ongeletterde groepe word in tabel 2 aangegee.

TABLE 2

STRESVLAK : GROEPE

\begin{tabular}{lrrrrr}
\hline \multicolumn{1}{c}{ GROEP } & $\mathbf{X}$ & $\mathbf{S}$ & $\mathbf{n}$ & $\mathbf{F}$ & $\mathbf{P}$ \\
\hline $\begin{array}{l}\text { Ongeletterde } \\
\text { groep }\end{array}$ & 96,97 & 22,60 & 30 & 3,21 & $0,00 \star \star$ \\
$\begin{array}{l}\text { Geletterde groep } \\
\star\end{array}$ & 74,67 & 20,17 & 30 & & \\
$\begin{array}{l}\star \mathrm{p} \leq 0,05=\text { beduidend } \\
\star \star \mathrm{p} \leq 0,01=\text { hoogs beduidend }\end{array}$ & & & & &
\end{tabular}

Volgens die variansieontleding (sien tabel 2), was die verskille in gemiddelde stresvlakke tussen die twee groepe hoogs beduidend $(p=0,00)$. Ter wille van volledigheid word besonderhede (gemiddelde en standaardafwykings) ook in tabel 2 aangegee.

Tabel 2 toon dat ongeletterde swart werknemers 'n beduidend hoër vlak van stres as die geletterde groep ervaar.
Die eerste teoretiese hipotese, naamlik dat swart geletterde en ongeletterde werknemers beduidend verskillende stresvlakke ervaar, word dus aanvaar.

\section{Oorsake van stres: verskille tussen groepe}

Die oorsake van stres vir die geletterde en ongeletterde groepe word in tabel 3 aangedui. Meer gedetailleerde inligting word gegee oor oorsake van stres wat beduidend verskillende tellings tussen die groepe opgelewer het (sien tabel 4).

TABLE 3

OORSAKE VAN STRES : GROEPE

\begin{tabular}{|c|c|c|c|c|c|c|}
\hline \multirow{2}{*}{$\begin{array}{l}\text { OORSAKE VAN STRES } \\
\text { VERANDERLIKES }\end{array}$} & \multicolumn{3}{|c|}{$\begin{array}{l}\text { ONGELETTERDE } \\
\text { GROEP } \\
(\mathrm{N}=30)\end{array}$} & \multicolumn{3}{|c|}{$\begin{array}{l}\text { GELETTERDE } \\
\text { GROEP } \\
(\mathrm{N}=30)\end{array}$} \\
\hline & $\mathbf{X}$ & $\mathbf{S}$ & $\mathbf{X}$ & $\mathbf{S}$ & $\mathbf{F}$ & $\mathbf{P}$ \\
\hline Oorsake binne werk: & 17,87 & 4,78 & 18,80 & 6,45 & 1,16 & 0,52 \\
\hline - Organisasie funksionering & 37,90 & 5,91 & 46,70 & 9,10 & 3,0 & $0,00 \star \star$ \\
\hline - Taakeienskappe & 17,90 & 5,60 & 22,30 & 6,55 & 4,10 & $0,00 \star \star$ \\
\hline $\begin{array}{l}\text { - Fisieke werksomstandighede } \\
\text { en werkstoerusting }\end{array}$ & 19,27 & 5,60 & 22,30 & 6,55 & 4,10 & $0,00 \star \star$ \\
\hline - Loopbaan aangeleenthede & 21,17 & 4,58 & 23,97 & 4,64 & 1,11 & $0,02 \star \star$ \\
\hline $\begin{array}{l}\text { - Sosiale aangeleenthede } \\
\text { - Vergoeding, byvoordele }\end{array}$ & 19,40 & 6,91 & 23,90 & 9,94 & 1,18 & $0,04^{\star}$ \\
\hline $\begin{array}{l}\text { en personeelbeleid } \\
\text { - Oorsake buite die werk }\end{array}$ & 46,03 & 8,86 & 36,50 & 8,58 & 3,37 & $0,00 \star \star$ \\
\hline
\end{tabular}

${ }^{\star} \mathrm{p} \leq 0,05=$ beduidend

$\star \star \mathrm{p}<0,01=$ hoogs beduidend

TABLE 4

*OORSAKE VAN STRES (GEDETAILLEERDE INLIGTING) $\mathbf{N}=\mathbf{6 0}$

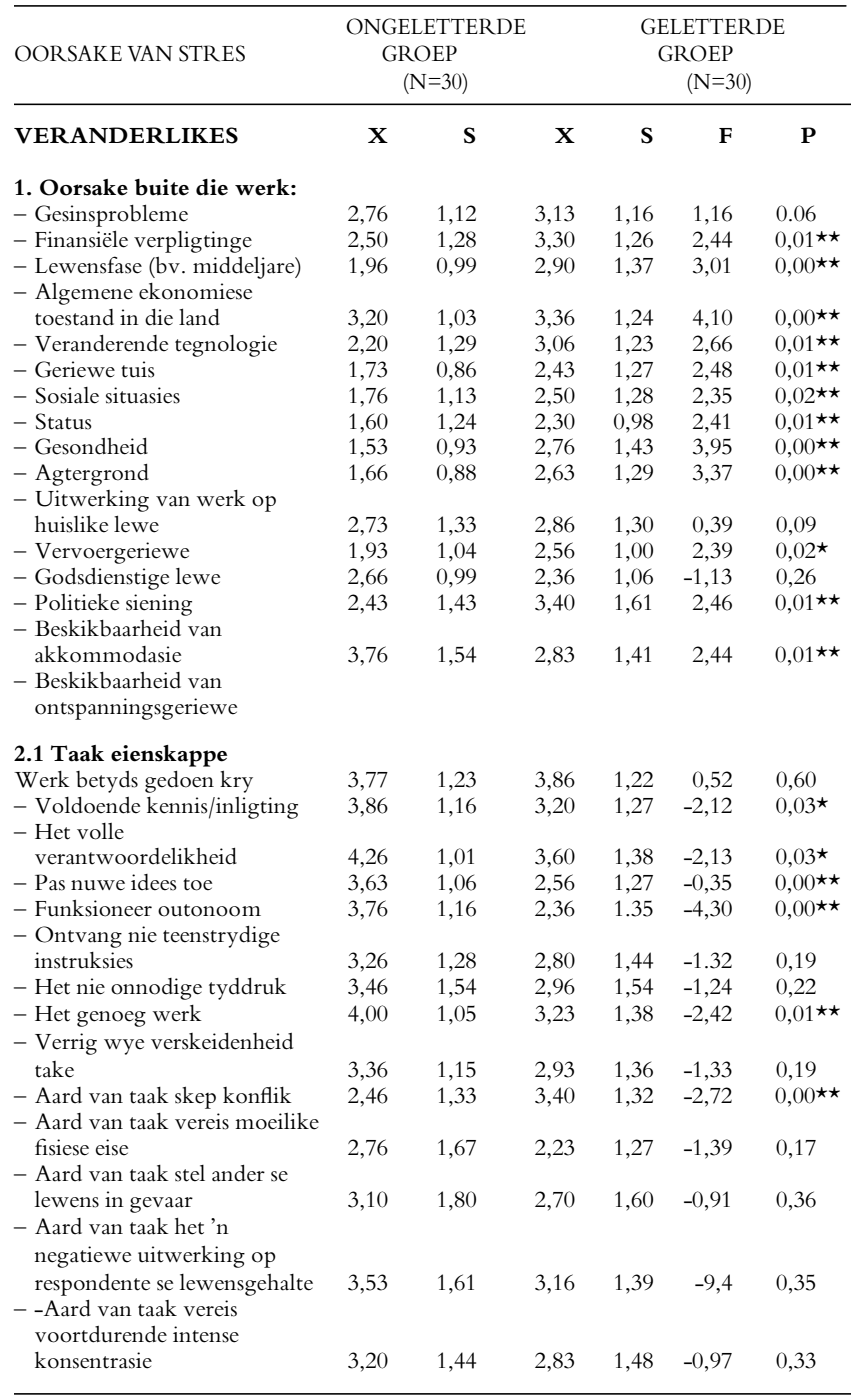

$\star \mathrm{p} \leq 0,05=$ beduidend

$\star \star \mathrm{p} \leq 0,01=$ hoogs beduidend 


\begin{tabular}{|c|c|c|c|c|c|c|}
\hline \multirow{2}{*}{$\begin{array}{l}\text { OORSAKE VAN STRES } \\
\text { VERANDERLIKES }\end{array}$} & \multicolumn{3}{|c|}{$\begin{array}{l}\text { ONGELETTERDE } \\
\text { GROEP } \\
(\mathrm{N}=30)\end{array}$} & \multicolumn{3}{|c|}{$\begin{array}{l}\text { GELETTERDE } \\
\text { GROEP } \\
(\mathrm{N}=30)\end{array}$} \\
\hline & $\bar{X}$ & $\mathbf{S}$ & $\bar{X}$ & $\mathbf{s}$ & $\mathbf{F}$ & $\mathbf{P}$ \\
\hline \multicolumn{7}{|l|}{$\begin{array}{l}\text { 2.2 Fisiese werksomstandig- } \\
\text { hede en werkstoerusting }\end{array}$} \\
\hline $\begin{array}{l}\text { - Beskikbaarheid van werks- } \\
\text { toerusting } \\
\text { - Werkstoerusting in goeie }\end{array}$ & 3,70 & 1,34 & 2,83 & 1,41 & $-2,43$ & $0,01 \star \star$ \\
\hline & 4,23 & 1,07 & 3,20 & 1,40 & $-3,21$ & $0,00 \star \star$ \\
\hline werksomstandighede & 3,80 & 0,21 & 2,60 & 1,35 & $-3,61$ & $0,00 \star \star$ \\
\hline \multicolumn{7}{|l|}{ 2.3 Sosiale angeleentehde } \\
\hline $\begin{array}{l}\text { - Geniet hoë status } \\
\text { - Handhaaf positiewe } \\
\text { verhouding met toesig_- }\end{array}$ & 4,40 & 0,93 & 3,83 & 1,17 & $-2,13$ & $0,03 \star$ \\
\hline $\begin{array}{l}\text { houers } \\
\text { - Handhaaf positiewe }\end{array}$ & 3,60 & 1,24 & 3,36 & 1,54 & $-.0,64$ & 0,52 \\
\hline verhouding met kollegas & 4,20 & 0,96 & 3,66 & 1,24 & $-1,86$ & $0,00 \star \star$ \\
\hline - Sosiale eise is billik & 3,76 & 1,08 & 3,20 & 1,24 & $-1,66$ & 0,10 \\
\hline \multicolumn{7}{|c|}{$\begin{array}{l}2.4 \text { Vergoeding, byvoordele en } \\
\text { personeelbeleid }\end{array}$} \\
\hline $\begin{array}{l}\text { - Voldoende vergoeding } \\
\text { (salaris) }\end{array}$ & 2,36 & 1,21 & 1,70 & 1,14 & $-2,18$ & $0,03 \star$ \\
\hline - Voldoende byvoordele & 3,36 & 1,42 & 2,66 & 1,84 & $-2,07$ & $0,4 \star$ \\
\hline - Regverdige personeelbeleid & 3,36 & 1,24 & 2,73 & 1,25 & $-1,96$ & $0,06^{\star}$ \\
\hline
\end{tabular}

Volgens die resultate verskil die volgende oorsake van stres hoogs beduidend tussen die twee groepe: oorsake buite die werksituasie asook oorsake binne die werksituasie, naamlik taakeienskappe en fisiese werktoestande asook werktoerusting. Sosiale aangeleenthede, vergoeding en byvoordele verskil ook beduidend tussen die twee groepe. Geen beduidende verskille is ten opsigte van die volgende oorsake in die werksituasie gevind nie: funksionering van die organisasie en loopbaangeleenthede (sien tabel 3).

Wat oorsake buite die werksituasie betref, het die laervlak groep beduidend hoër tellings (met ander woorde hoër stres) ten opsigte van die volgende faktore behaal: geldelike verpligtinge, lewensfase, veranderende tegnologie, geriewe tuis, sosiale situasie, status, gesondheid, agtergrond, effek van werk op huislike lewe, godsdienstige lewe en beskikbaarheid van akkommodasie, (die geletterde groep het egter 'n beduidend hoër telling ten opsigte van die beskikbaarheid van ontspanningsgeriewe behaal.). Geen beduidende verskil tussen algemene ekonomiese situasie, gesinsprobleme, politieke siening en vervoergeriewe is gevind nie (sien tabel 4).

Ten opsigte van oorsake binne die werksituasie het die ongeletterde groep beduidend hoër strestellings as die geletterde groep ten opsigte van takeienskappe behaal, naamlik nie genoeg kennis/inligting om die werk gedoen te kry nie, nie volle verantwoordelikheid om die werk gedoen te kry nie, nie in staat om nuwe idees toe te pas nie, kan nie outonoom funksioneer nie en nie genoeg werk om besig te bly nie. In teenstelling hiermee het die geletterde groep beduidend hoër strestellings ten opsigte van die volgende behaal: die aard van take veroorsaak konflik met ander mense.

Voorts het die ongeletterde groep beduidend hoër strestellings ten opsigte van fisiese werksomstandighede en werktoeruting behaal as die geletterde groep. Verskille ten opsigte van die volgende faktore (as deel van fisiese werksomstandighede en werktoerusting) is geïdentifiseer: beskikbaarheid van werktoerusting (byvoorbeeld skryfbehoeftes, gereedskap, elektriese en laboratoriumtoerusting) asook of dit in $n$ behoorlike werkende toestand is en om toegelaat te word om in toereikende fisiese werkstoestande (byvoorbeeld beligting, temperatuur en kantoorruimte) te funksioneer.

Wat sosiale aangeleenthede betref, het die ongeletterde groep beduidend hoër strestellings as die geletterde groep ten opsigte van die volgende verkry: geniet nie 'n hoë status nie, nie in staat om positiewe verhoudings met kollegas te handhaaf nie.

Laastens, wat aspekte soos toereikende vergoeding (salaris) en byvoordele (byvoorbeeld behuisingsubsidie) betref, het die ongeletterde groep ook beduidend hoër stresvlakke as die geletterde groep behaal.

Die tweede teoretiese hipotese, naamlik dat swart geletterde en ongeletterde werknemers beduidend verskillende tellings vir oorsake van stres behaal, word dus ook aanvaar.

\section{AANBEVELINGS EN GEVOLGTREKKLNGS}

\section{Vlakke van stres}

Dit blyk dat die ongeletterde swart werknemers beduidend hoër stresvlakke as die geletterde werknemers ervaar.

Spesiale aandag moet dus aan ondersteuning vir ongeletterde swart werknemers gegee word om moeilike eise van die omgewing te hanteer. Opleiding oor wat stres is en hoe om lewensvaardighede te gebruik om moeilike eise te hanteer, moet dus beklemtoon word. Voorts moet 'n groter poging aangewend word om laervlakwerknemers tot gepaste geletterheidsvlakke op te lei. French $(1990$, p. 4) is van mening dat geletterde werknemers meer selfvertroue het omdat hulle meer toegang tot geleenthede het (byvoorbeeld bevordering) en hul opinies tel meer wat hulle dus 'n magsbasis gee. Hulle glo dus dat hulle hulle omstandighede kan beïnvloed (interne lokus van beheer) wat bydra tot die hantering van moeilike eise en stressors. Darkenwald en Merrian (1982, p. 51) voer aan dat die basiese doel van geletterheidsopleiding is om mense te help om op fisiese, psigologiese en sosiale wyse te oorleef ten einde hulle in staat te stel om by moeilike omstandighede aan te pas en meer betekenis aan hulle bestaan te gee. Deur geletterd te word, kan werknemers dus hulle lewensgehalte verbeter en moeilike eise doeltreffend hanteer wat' $n$ positiewe uitwerking op produktiwiteit behoort te hê (Darkenwald \& Merrian, 1982, p 51; French, 1990, p 5). en op hulle vermoë om stres te hanteer.

\section{Oorsake van stres}

Gegrond op die resultate blyk dit dat ongeletterde werknemers geneig is om in'n groter mate as die geletterde groep, probleme te ondervind met oorsake van stres, binne sowel as buite die organisasie.

Hoë strestellings ten opsigte van oorsake buite die werksituasie vir die ongeletterde groep kan moontlik toegeskryf word aan die huidige ekonomiese en politieke situasie waar werknemers onder andere afgedank word en baie veranderinge plaasvind. Ngwezi (1988) is van mening dat 'n swak ekonomiese situasie veral deur ongeletterde mense gevoel word vanweë hulle beperkte bronne/opsies om maniere te vind om hul situasie te verbeter. Ander redes kan moontlik aangevoer word, maar moet deur middel van verdere navorsing bepaal word. Werknemers moet dus in ag neem dat ongeletterde werknemers baie stressors buite die werkomgewing ervaar en kan hulle probeer ondersteun deur middel van byvoorbeeld behuising en mediese steun, ontwikkelingskursusse en ander opvoedkundige steun, regs- en huweliksadvies, vervoer en geldelike steun, ontspanningsgeriewe, ens. Geletterde werknemers kan buite die werksituasie gesteun word deur ontspanningsgeriewe te skep (byvoorbeeld vir muurbal en gholf).

Wat oorsake van stres binne die organisasie betref, het die ongeletterde groep hoogs beduidende laer tellings (hoër stres) as die geletterde groep ten opsigte van taakeienskappe, fisiese werksomstandighede en werktoerusting behaal. Beduidende verskille in tellings is ook ten opsigte van sosiale aangeleenthede, vergoeding en byvoordele gevind.

Bogenoemde resultate kan dui op'n behoefte onder laervlakwerknemers om die geleentheid te hê om hulle vaardighede binne toereikende fisiese werksomstandighede te verbeter sodat taakeise meer effektief binne hierdie konteks gehanteer 
kan word. Werkgewers moet seker maak dat veral laervlakwerknemers die geleentheid kry om nuwe idees toe te pas, oor voldoende inligting beskik en volle verantwoordelikheid het om hulle werk te doen, outonoom kan funksioneer en genoeg werk het om hulle besig te hou. Voorts kan aspekte soos voldoende vergoeding en byvoordele en die gevoel by laervlakwerknemers dat hulle 'n positiewe status in die onderneming het ook die gevolg wees van die doeltreffende hantering van taakeise. Deur stressors in die werksituasie te verminder (soos hierbo beskryf) sal veral laervlakwerknemers beter geleenthede en motivering hê om teen optimale prestasievlakke te werk, vinniger leer en ontwikkel, minder stres ervaar en meer produktief wees waardeur beide werknemer en werkgewer sal baat. Geletterde werknemers kan binne die werksituasie ondersteun word deur hulle in konflikhantering en kommunikasievaardighede op te lei.

Ten slotte, in die lig van die hoë stresvlakke by Suid-Afikaners (soos reeds bespreek) behoort groter klem gelê te word op die voorkoming van hoë stresvlakke by werknemers (veral by ongeletterde werknemers) in ondernemingverband. Werkgewers/sielkundiges kan 'n belangrike rol hierin speel deur op die resultate van hierdie studie te fokus.

\section{VERWYSINGS}

Auerbach, S.M. \& Gramling, S.E. (1998). Stress management; Psychological foundations. New Jersey: Prentice Hall

Barnett, R.C. \& Brennan, R.T. (1995). The relationship between job experiences and psychological distress: a structural equation approach. Journal of Organizational Behavior, 16(3), 259276

Bartlett, D. (1998). Stress: perspectives and processes. Buckingham: Open University Press

Cartwright, S.C. \& Cooper, C.L. (1997). Managing workplace stress. London: Sage

Cooper, C.L. \& Sutherland, V.J. (1990). Understanding Stress. London: Chapmann \& Hall.

Cox, T. (1978). Stress. London: Macmillan.

Davies, B. (1986). The environment influences on black manager performance. Black advancement, 4, 3-7.

Darkenwald, G.G. \& Merrian, S.B. (1982). Adult education: foundations of practise. New York: Harper \& Row.

French, E. (1990). Literacy and the private sector in South Africa: lessons from the eighties. 1PM Journal, 8(10), 4-10.

Gatto, R.P. (1991). Controlling stress in the workplace. Pittsburgh: GTA

Gerdes, L.C. (1992). Impressions and questions about psychology and psychologists. South African Journal of Psychology, 22(2), 39-43.

Keenan. A. \& Newton, T.J. (1984). Frustration in organizations; Relationships to role stress, climate and psychological strain. Journal of Occupational Psychology, 57(1), 57-65.
Lazarus, R.S. (1991). Psychological stress in the workplace. In P.L. Parrewe (Ed)., Handbook on Job Stress. Madeara: Select Press.

Lazarus, R.S. (1994). Psychological stress in the workplace. In P.L. Parrewe \& R. Crandall (Eds.) Occupational stress: A handbook. New York: Taylor \& Francis

Lazarus, R.S. (1999). Stress and emotion. New York: Springer.

Ludik, I.J.G. (1988). Stress and the nurse. Ongepubliseerde M.Com.- verhandeling, Universiteit van Pretoria, Pretoria.

Moerdyk, A.P. (1983). Black advancement and stress: A literature review and conceptual synthesis. Johannesburg: Nasionale Instituut vir Personeelnavorsing.

Ngwezi, A.A. (1989). Stress levels and coping styles amonost teachers. Ongepubliseerde M.A.-verhandeling, Universiteit van Pretoria, Pretoria.

Olivier, C. (1989). Kursus: objektiewe evaluering. Pretoria: Universiteit van Pretoria.

Outlaw, F.H. (1993). Stress and coping: the influence of racism in the cognitive appraisal processing of Americans. Issues in mental Health. 14(4), 399-404.

Patel, C. (1991). The complete guide to stress management. New York: Plenum.

Pienaar, J.W. (1998). Verskille in werkstres en psigiese uitbranding tussen blanke en swart middelvlakbestuurspersoneel in 'n Suid-Afrikaanse diensorganisasie. Ongepubliseerde M.Soc.Sc.-verhandeling, Universiteit van die Oranje Vrystaat, Bloemfontein.

Prins, H. (1995). Die effek van regstellende aksie op 'n groep administratiewe werknemers soos dit blyk uit hy ervaring van stres. Ongepubliseerde B .P.L.verhandeling, Universiteit van die OranjeVrystaat, Bloemfontein.

Reese, K. (1981). Black managers in white businesses. Business South Africa, 16(8), 22-25

Smallegan, M. (1989). Level of depressive symptoms and life stresses for culturally diverse older adults. The Gerontologist, 29(1), 45-51.

Smith, J.C. (1993). Understanding stress and coping. New York: MacMillan.

Sullivan, CA. (1995). A salutogenic study of stress. Ongepubliseerde M.A.-verhandeling, Randse Afrikaanse Universiteit, Johannesburg.

Van Graan, F. (1981). Workstress: An psychological investigation. Ongepubliseerde doktorale proefskrif, Potchefstroomse Universiteit, Potchefstroom.

Van Zyl, E.S. (1991). The Development of a measuring instrument of workstress among high level employees. Ongepubliseerde doktorale verhandeling, Universiteit van Pretoria, Pretoria.

Van Zyl, E.S. (1996). The experience of stress amongst higher level black employees. Acta Academica, 2 8(2), 39-43.

Van Zyl, E.S. \& Van der Walt, H.S. (1994). Die ontwikkeling van 'n meetinstrument van werkstres. South African Journal for Industrial Psychology, 20(4), 22-28.

Watts, J.C. (1985). Black managers and their work colleagues in selected industrial organizations in Natal. Ongepubliseerde doktorale verhandeling, Universiteit van Natal, Durban. 